Феномен жизнестойкости является наиболее общей интегральной характеристикой личности, представляющей собой паттерн смысложизненных ориентаций, самоотношения, стилевых характеристик поведения, который опирается на природные свойства личности, но в большей степени носит социальный характер. Учитывая факт, что у подростков со слаборазвитым интеллектуально-волевым потенциалом наблюдаются депрессии, неустойчивые эмоциональные состояния и склонности к девиантному поведению можно рекомендовать психологам в целях повышения жизнестойкости посредством психокоррекционой работы у подростков развивать интеллектуальную сферу.

$$
* * *
$$

1. Александрова Л.А. К концепции жизнестойкости в психологии// Сибирская психология сегодня: Сб. научн. трудов. Вып. 2/ Под ред. М.М. Горбатовой. - Кемерово: Кузбассвузиздат, 2004.; Книжникова С.В. Педагогическая профилактика девиантного поведения на основе формирования жизнестойкости (Монография). - Краснодар: «АСВ-полиграфия», 2009.; Тышкова М. Исследование устойчивости личности детей и подростков в трудных ситуациях. // Вопросы психологии. - 1987. - №1. Выготский Л.С. Психология. М.: Изд-во ЭКСМО-Пресс, 2002 - 1008 с. Корнилов И.А. Саморегуляция человека в условиях социального перелома. //Вопр. психол. 1995. - № 5. - 69-78с.

2. Анцыферова Л.И. Личность в трудных жизненных условиях: переосмысление, преобразование ситуации и психологическая защита // Психол. журн. 1994. - Т. 14. - № 2

3. Коробейников И.А. О некоторых особенностях формирования интеллекта детей в условиях психической депривации // Дефектология. - 1990. - № 3.

4. Леонтьев Д.А., Рассказова Е.И. Тест жизнестойкости. - М.: Смысл, 2006. — 63с.

5. Логинова М. В. Психологическое содержание жизнестойкости личности студентов: дисс. канд. психол. наук. М., 2010. - 225c.

6. Смирнова Н.Л. Исследование имплицитных концепций интеллекта // Психология личности в условиях социальных изменений. - М., 1993. - 209c.

7. Формирование жизнестойкости и совладания с трудными жизненными и стрессовыми ситуациями детей и подростов в образовании: учебно-методическое пособие // Сост.: М.В. Шамардина, Т.А. Матерова, Н.А. Першина - 2-е изд. - Бийск: АГГПУ им.В.М. Шукшина, 2016. - 190с.

\title{
Нургалиева Г.Ф. \\ Гиперактивность как фактор отклоняющегося поведения в младшем школьном возрасте
}

(Россия, Уфа)

doi: $10.18411 / l j-31-01-2018-21$

idsp: 000001:lj-31-01-2018-21

\section{Аннотация}

В статье поднимается актуальная проблема так называемого омолаживания отклоняющегося поведения. Предпосылки его проявлений, по мнению автора, кроются в гиперактивности детей младшего школьного возраста. В связи с данным обстоятельством автор считает необходимым проводить профилактику и коррекцию гиперактивного поведения младших школьников для предотвращения различных форм девиаций в подростковом возрасте.

Ключевые слова: гиперактивность, младший школьный возраст, отклоняющееся поведение.

\section{Abstract}

Article climbs the actual problem of the so-called rejuvenation of deviant behavior. The premise of its manifestations, in the author's opinion, lie in the hyperactivity of children of primary school age. In this circumstance, the author considers it necessary to carry out the prevention and correction of the hyperactive behavior of junior schoolchildren to prevent various forms of deviations in adolescence.

Keywords: hyperactivity, primary school age, aberrant behavior. 
На сегодняшний день проблема социальной девиации или девиантного (отклоняющегося) поведения у детей актуальна во многих учреждениях дошкольного, среднего и дополнительного образования. Отклоняющееся поведение имеет место не только в школе, в учебной деятельности, но и распространяется на все сферы жизни ребенка, главным образом, на его взаимодействия с окружающими.

Школа - это определенная система норм, правил, требований, определяющих взаимоотношения ребенка с педагогическим коллективом и со сверстниками. Из какой бы семьи не пришел ребёнок в школу, к нему предъявляются определенные требования и он должен соответствовать им. Комфортность пребывания ребенка в школе определяется отношением к нему образовательного учреждения. В настоящее время в образовтельных учреждениях России наиболее благоприятные условия для обучения и развития детей с определенными проблемами в развитии.

Актуальность проблемы обусловлена усугубляющейся тенденцией к увеличению количества подростков, имеющих отклонения в поведении.

Иногда дети ведут себя грубо не только по отношению друг к другу, но и к учителю, воспитателю, родителю. Ученики нарушают дисциплину и правила поведения в школе: опаздывают на уроки, во время занятия невнимательны и вялы или, наоборот, вспыльчивы и импульсивны. В последнее время участились случаи, когда дети наносят друг другу серьёзные физические увечья, нарушают социальные нормы и правила в обществе.

Практически вся жизнь любого общества характеризуется наличием отклонений. Социологи называют отклоняющееся поведение девиантным. Оно подразумевает любые поступки или действия, не соответствующие писаным или неписаным нормам. Девиантное поведение - это устойчивое в данный период времени поведение человека, которое противоречит нормам социального поведения в том или ином обществе, причиняет ущерб окружающим и самому себе.

Важно отметить, что в младшем школьном возрасте девиантное поведение часто связано с гиперактивным поведением и в последнее время имеет тенденцию к омолаживанию, проявляясь еще в дошкольный период, мешая ребенку в учебной деятельности и построении взаимоотношений со сверстниками уже с первых дней обучения в школе.

В младшем школьном возрасте, по мнению В.М. Целуйко, наиболее распространенными являются такие формы отклоняющегося поведения, как непослушание, выражающееся в шалостях, озорстве, проступках; детский негативизм, проявляющийся в упрямстве, капризах, своеволии, недисциплинированности и пр.[6] .

Г.И. Колесникова, характеризуя девиации, преобладающие в детском возрасте, называет: фобии, поведенческие проблемы (например, агрессия - аутоагрессия), проблемы адаптации, низкая успеваемость[2].

Некоторые аспекты изучаемой нами проблемы исследовали отечественные и зарубежные авторы С.А. Беличева, М. Вебер, Л.С. Выготский, Э. Дюркгейм, В.П. Кащенко, Ю.А. Клейберг, Д.И. Фельдштейн, Э. Фромм, С.Т. Шацкий, и другие. Оформление проблемы девиации как относительно самостоятельного явления берет свое начало не в рамках психологии, а в социальных и криминологических трудах.

Отклоняющимся называют поведение, которое не соответствует нормам и ролям. При этом одни ученые предпочитают в качестве точки отсчета («нормы») использовать экспектации (ожидания) соответствующего поведения, а другие - аттитюды (эталоны, образцы) поведения. Некоторые полагают, что отклоняющимися могут быть не только действия, но и идеи.

В психологической литературе отклоняющимся называется поведение, отклоняющееся от социально-психологических и нравственных норм, либо как ошибочный антиобщественный образец решения конфликта, проявляющийся в 
нарушении общественно принятых норм, либо в ущербе, нанесенном общественному благополучию, окружающим и себе.

Несмотря на некоторые различия, все авторы главным критерием девиаций считают нарушение норм, принятых в данном обществе.

Гиперактивность представляет собой повышенный уровень активности человека, а также возбудимости его нервной системы. Она является распространенным явлением именно в младшем школьном возрасте.

Отклоняющееся поведение год от года требует повышенного внимания, так как приобретает в последние годы угрожающий характер. Все больше семей находится под наблюдением социальных служб. Объяснить причины, условия и факторы, порождающие это социальное явление, с учетом происходящих изменений в современном обществе, давольно нелегко. Работа над этими проблемами предполагает поиск ответов на ряд вопросов, среди которых вопрос о склонности к девиантному поведению.

Несмотря на то, что этой проблемой занимаются педагоги, психологи, дефектологи, логопеды, психиатры, некотрые родители и педагоги все еще считают, что гиперактивность поведенческой проблемой и только, а иногда и просто «распущенностью» ребенка или результатом неправильного воспитания.

Гиперактивное поведение в младшем школьном возрасте носит неустойчивый и вариативный характер, a, следовательно, легче поддается профилактической и коррекционной работе. В связи с данным обстоятельством считаем необходимым, проводить профилактику и коррекцию гиперактивного поведения именно в младшем школьном возрасте для предотвращения различных форм девиаций в подростковом возрасте.

$$
* * *
$$

1. Беличева С. А. Основы превентивной психологии. - М.: Редакционно-издательский центр консорциума «Социальное здоровье России», 1993. -199 с.

2. Колесникова, Г. И. Социология и психология семьи : учебник для академического бакалавриата / Г. И. Колесникова. - 2-е изд., испр. и доп. - М. : Издательство Юрайт, 2016. — 397 с.

3. Невский И.А. Учителю о детях с отклонениями в поведении. М., 1993.

4. Руденский Е.В. Психология ненормативного развития личности. -Новосибирск, 2000.

5. Степанов В.Г. Психология трудных школьников. - М., 1988.

6. Ц Целуйко В.М. Вы и ваши дети. Психология семьи. Роств-на-Дону: Феникс, 2004. 283 с.

7. Шнейдер Л.Б. Девиантное поведение детей и подростков. - М.: Академический Проект; Трикста, 2005.

\section{Доровских О.А., Шамардина М.В. \\ Библиотерапия метод психокоррекции в работе с созависимыми подростками}

Алтайский государственный университет (Россия, Барнаул)

doi: $10.18411 / l j-31-01-2018-22$

idsp: 000001:lj-31-01-2018-22

\section{Аннотация}

Авторами в работе представлен теоретико-методологический анализ проблематики созависимого поведения личности; определена природа данного состояния, обоснован метод библиотерапии для психокорекционной работы с созависимыми подростками. В данной работе содержательно раскрывается специфика метода библиотерапии в работе с созависимыми подростками: цели, этапы и подбор видов литературных источников. Обобщены выводы проведенного исследования и это позволило показать, что посредством метода библиотерапии наблюдается изменения созависимых состояний личности, способствуют осознанию собственных проблем, разделению чувств с другими, формированию мотивации к изменениям, уменьшению страховпоявлению новых 